\title{
The Experience of Reconstructing Historic Buildings in Practice: Selected Cases From the Czech Republic
}

\author{
Josef Štulca
}

\begin{abstract}
A negative attitude to the physical reconstruction of damaged or destroyed historic structures back to their original forms has been deeply rooted in the Czech heritage conservation philosophy since the beginning of the twentieth century. Under the influence of practices abroad, Czech conservators have, however, in some cases, accepted reconstruction. This paper seeks to illustrate the process of continuously oscillating between the refusal and the acceptance of reconstruction in the Czech Republic, with selected cases taken from heritage conservation practice-namely, the facades on the north side of the main square in the historic town of Nové Město nad Metuji in east Bohemia (1952-1954), the western facade of the Emmaus Abbey Church in Prague (1964-1966), Stone Bell House in Prague (1974-1988), and the spires and gables of the Lesser Town town hall in Prague (2007-2008). They show how much the quality and the regard to historical faithfulness of the execution matters in reconstruction and how useful it is in this process to follow the principles of the Charter of Venice, an international document on heritage conservation issued in 1964, which, despite some recent objections, is still far from obsolete.
\end{abstract}

\section{Keywords}

Heritage conservation, reconstruction, historical authenticity, credibility, historicism, modernism

A negative, sometimes even hostile, attitude to the physical reconstruction of partly damaged or totally destroyed historical buildings back to their original forms has been deeply rooted in the minds of Czech conservators since the early decades of twentieth century. They were highly active in the dramatic changes being made in the theory of heritage conservation in central Europe about 1900 by the great scholars Georg Dehio (Mörsch 200: 121-133), Alois Riegl (Pächt 1963: 188-199), and the Bohemian-born Max Dvořák (Pavel 1973: 225-390). Simultaneously with early modernism in architecture, heritage conservation, too, rejected any form of historicism that was so typical of the so-called "stylistic restorations" of monuments in the second half of nineteenth century. Modern heritage conservation, which had just been born, combined two methods: the analytical presentation of archaeological remnants discovered during the archaeological investigations of the historic building to be conserved and an uncompromising modernism of forms in all the elements added to it. With this approach, the use of any historic architectural forms was strictly forbidden

aTechnology University in Prague, Czech Republic

Correspondent Author:

Josef Štulc, National Heritage, Wallenstein Square 3, 11801

Prague 1, Czech Republic 
(Štorm 1959: 57-68).

Václav Wágner, an important Czech conservator, sought to overcome this one-sided approach in the late of 1930s and 1940s. He accepted the scientifically based reconstruction of missing historic elements in their original historic forms in order that the integrity of the architectural composition of historic buildings would be respected or regained (Wagner 2005: 28; Štulc 2011: 187-194). His holistic, synthetic approach, however, met with strong opposition: Most Czech conservators considered it a heresy, arguing that it would drive heritage conservation back to the practices of the nineteenth century, which they condemned (Wirth 1942-1943: 123-126).

The analytical and modernistic approach, firmly anchored in Czech conservation philosophy and in its justification confirmed by some very successful projects in practice (this includes the admirable work of Josef Plečnik on Prague castle, Pavel Janak's conservation and modern enlargement of Czernin House in Prague for the Foreign Ministry, Jaroslav Fragner's restoration, and new wing of the historic complex of Prague University) was practised in Czechoslovakia up to the 1950s and became almost a rigid doctrine. But even its most devoted followers could not entirely ignore what was going on in the neighbouring central European countries at that time. The Second World War, so destructive to human lives and material objects, turned much of the architectural heritage of Europe into ruins. After the war, a response to the enormous losses was a great amount of faithful reconstructions of ruined buildings, which was carried out over a few decades. This includes in central Europe, the whole historic core of Warsaw, St Stephan's Cathedral in Vienna, the Gothic churches of Nuremberg and Lübeck, the Baroque princely residences in Munich and Würzburg, and the Gothic town hall in Münster. They became truly heroic achievements of heritage conservation, not only in quantity but also in quality and historical credibility.
The work is almost unbelievable when one takes into consideration the post-war shortages of almost everything, particularly of skilled manpower in the countries devastated by the war ${ }^{1}$.

Perhaps because the allies refrained from massive bombing of the cities in occupied Czechoslovakia, the country largely escaped such destruction to its architectural heritage (Kibic and Vošahlík 2011: 17-24). Nevertheless, at that time, and probably due to the influence of grand reconstructions in the neighbouring countries, some important reconstruction work was undertaken here too. Particularly worthy of mention is the reconstruction of the medieval Bethlehem Chapel in Prague, where the great Czech religious reformer John Huss used to preach. The work was superbly designed by the architect Jaroslav Fragner, and included anastylosis, using all the archaeological remnants of the original Gothic structure (Kibic 1984: 29-40). In contrast, the large-scale reconstruction of all the facades on north side of the main square of the east Bohemian historic town Nové Město nad Metují, which was carried out from 1952 to 1954 (Juránek and Braný 1976), was far more questionable. The architect Jaroslav Vincík restored the row of town houses along its north side (whose facades had been remodelled in the eighteenth and early nineteenth centuries) to the unified Venetian Renaissance forms that the houses had in the 1530s. This ambitious project was based on conscientious, though insufficient, archaeological research of the buildings and was meant to continue on other sides of the square, but since the idea met with strong criticism and faced funding problems, it was cancelled. The majority of Czech conservators were strongly against such an approach ${ }^{2}$. Now it is, not unjustly, considered a manifestation of "Sorela", the Czechoslovak nickname for the then widely detested "Socialist Realism" in art and architecture. This was a historicizing style introduced into Czechoslovak art and architecture from the Stalinist Soviet Union after the Communist take-over in Czechoslovakia in 1948 
(Sedláková 1994). It is no wonder that soon after the most rigid period of the Communist dictatorship ended in the late 1950s, heritage conservation - together with the arts and architecture of the time, rejected historicism and returned to recent Western modernism (Strakoš 2014). Perhaps the clearest manifestation of this change in the field of conservation was the renewal of the western facade of the monumental Gothic church of the Emmaus Abbey in Prague, which had been severely damaged by American aerial bombardment on February 14, 1945. The winner of the competition of 1964 was the architect František Maria Černý. He conceived the new front of the church as two intersecting "angel's wings" in white béton brut (Švéda 2007: 203-215). The result, carried out in 1965-1968, is highly original, impressive, and beautiful. No wonder that it was soon, quite rightly, celebrated as evidence that a historic structure and high-quality modern architectural expression could co-exist extremely well (Dostál and Vošahlík 1965: 589-590).

Unfortunately, the new front of the Emmaus Church remained an isolated success. Czechoslovak architects of those times, happy that "Socialist Realism" with all its historicizing was over, became largely unconcerned about the history of architecture and the architectural heritage. Even worse, finding support amongst Communist rulers, bulky new buildings, using the modernist style of Brutalism, were ruthlessly erected in historic town centres throughout the country. In most cases, this was achieved at the cost of pulling down historic buildings and ignoring the integrity of the traditional settings (Kibic and Vošahlík 2011: 126-129). Disappointed with the poor results of the "new within the old" (Štulc 1988: 65-77; Štulc 2012: 57-71), many Czech conservators abandoned dogmatic modernism. Exceptionally and reluctantly, they came to terms with resuming reconstruction. The clearest evidence of this shift in opinion is the extremely ambitious reconstruction of the Gothic appearance of the "Stone
Bell House", situated in a prominent place on Old Town Square in Prague. Before its reconstruction, the building looked like a typical eighteenth century merchant's house, with a late Baroque stucco facade and a number of details of not negligible quality from the eighteenth century and later. In an extensive archaeological investigation of the building in the late 1960s, sensational discoveries were made on the site. Behind the Baroque cladding, a great deal of the original Gothic town palazzo remained preserved. It had probably been built for King John of Bohemia (of the House of Luxembourg) in what was then the most modern French Gothic style in the second quarter of fourteenth century (Mayer 1988: 97-126). Because of the highest artistic quality of the Gothic remains and with regard to the fact that the investigation and its extensive probes had cleared away irreversibly most of the Baroque stucco facade, it was decided to reconstruct the house in its original Gothic architectural form. This difficult and from the outset clearly problematic decision brought both cultural gains and losses. The demanding Gothic architecture of the house, including what was probably the throne room and two chapels, was brought to light, together with fragments of Gothic murals and sculptures. But much had to be sacrificed to reach this goal: the Baroque stucco facade, historic timber ceilings and roof beam constructions, the Rococo doors, and a number of other architectural details from the eighteenth and nineteenth centuries (only the moveable objects had survived and were put into repositories). Reconstruction reflected at best the sharp contrast between the rather poor standards of those times of the builders, with their insensitive handling of the original material substance of the house, and, by contrast, the great skill of the free-lance artist who performed the conservation-restoration work (Štulc 2007b: 310-315). Because the architectural composition of the ground-floor facade and a number of other architectural features of the original Gothic building remained unknown and 
therefore had to be invented, the reconstruction did not follow the basic principle of the Venice Charter, that fundamental heritage conservation document of 1964, which stated, in Article 9 (Petzet 2009: 11-13), that "restoration must stop where conjecture begins".

The reconstruction of the Stone Bell House, finished in 1988, was, from the start, highly criticized by many Czech conservationists of the period. After the "Velvet Revolution", which began in mid-November 1989, the "angry young men" of the Czech conservation community referred to it as to a most typical manifestation of the decadence and bad habits of Czechoslovak heritage conservation in the totalitarian, Communist period (Rykl and Škabrada 1996: 12-16). One-sided positions of this sort were gaining ground and became widespread. They threatened to lead to a situation in which the method of reconstruction would be excluded from the heritage conservation toolkit in the Czech Republic ${ }^{3}$.

But heritage conservation, its philosophy, methods, and practices are always evolving. Just over the border, in Dresden, a vast bottom-up initiative for the reconstruction of the Frauenkirche (Church of Our Lady), a masterpiece of German Baroque architecture built by Georg Bähr from 1729 to 1743, was undertaken, shortly after the reunification of Germany. Despite the initially reserved attitude of professional German conservators (Denkmalschutz 1993: 222; Fischer 1998: 7-10), this monumental stone structure, which had stood in total ruins as a war memorial since 1945, was reconstructed to its original appearance in an exemplary way from 1993 to 2005 . This great achievement was soon followed by reconstructions of other historic monuments in Germany (including the Golden Hall of the Augsburg Town Hall and recently, the Royal Palaces in Dresden and Berlin). And it certainly influenced the general attitude towards reconstruction in other European countries.

In the Czech Republic, the reconstruction of the
Frauenkirche became a much-quoted example in heated, quarrelsome discussions that preceded and attended a project of a similar nature: the reconstruction of the historic spires and gables of the former town hall of the Lesser Town in Prague. This very important historic building was designed in the style of North Italian Mannerism by an imperial court architect, Giovanni Maria Filippi, and was built in two phases from 1617 to 1619 and from 1628 to 1636 . In 1826, its dilapidated spires and gables were documented and then removed, and the otherwise well-preserved building remained in this simplified appearance up to our day (Kibic 2007: 290-300).

The initiative to reconstruct the missing parts of the town hall of the Lesser Town came from the City of Prague, which also set aside from its budget, the sum of money estimated for the task. The proposal was warmly received by some Czech professional conservators and collaborating specialists and vehemently rejected by others. In a few instances, this community became so sharply polarized in its opinions. After the matter had been debated five times in various academic and technical commissions, the reconstruction project won. The reference to the undeniable success of the reconstruction of the Frauenkirche in Dresden certainly played a role in the final decision. Following the thorough archaeological investigation of the building, and taking into account the abundant historical iconography and the measurement survey elaborated in 1826 , before the missing parts were dismantled, the spires and gables were reconstructed, in 2007-2008, in the forms, structures, and materials practically identical to the originals (Karásek 2007: 307-309).

Comparing the reconstruction of Stone Bell House from the 1970s and 1980s and the much later reconstruction of Lesser Town town hall, we see considerable differences. In the first case, valuable historic constructions, masonry, and details had to be sacrificed to carry out the project, whereas the second case avoided any such losses. The building contractor 
in second case was much more qualified and disciplined. The construction firm carried out excellent craftsmanship using the same traditional materials and artisan techniques as when the building was first built in the early seventeenth century. The town-planning impact of the reconstructed spires of the town hall proved to be positive, too. And, last but not least, unlike the reconstruction of the Gothic Stone Bell House, the reconstruction of the spires and gables of the Lesser Town town hall was based on reliable and sufficient sources of information, and thus adhered to the principles of the Venice Charter (Štulc 2007b: 310-315).

\section{CONCLUSIONS}

The international discussion on reconstruction in heritage conservation initiated by the UNESCO (United Nations Educational, Scientific and Cultural Organization) and taking place on the board of ICOMOS (International Council on Monuments and Sites) is not over yet (ICOMOS 2013; Araoz 2015). It seems to be compelling further development of heritage conservation to become much more tolerant of reconstruction (ICOMOS 2017), perhaps because of the global present trend to diminish the importance of physical features in favour of intangible message of heritage (Araoz 2012: 47-52; Petzet 2012: 261-263). This discussion, however, is accompanied by a certain diminishing of the respect that, in heritage conservation in European countries, has traditionally been paid to academics, scientists, and specialists, and an increasing willingness to pay attention to the feelings and tastes of communities (Soós 2011: 73-100). Thus John Ruskin's and Alois Riegl's “value of age" (Alterswert) is giving ground to the more easily understandable, seemingly more attractive "value of newness" (Neuheitswert), which clearly prefers reconstruction to the mere conservation of historic buildings. In this context, the Venice Charter is sometimes said to be obsolete. The Czechoslovak and, later, Czech experience with reconstruction in practice advocates a different view. That practice has taught us that if we wish the reconstruction of a historic building to be credible, it pays to follow the Venice Charter's spirit and principles. Only under such conditions can reconstruction be acknowledged to be a relevant method of heritage conservation.

\section{Notes}

1. In contrast with those achievements, many historic buildings that had survived the war were cleared away to make room for new transport, commerce, and housing during the process of rapid post-war economic recovery (Kiesow 2012: 38-46).

2. Their strong disagreement is known only from oral tradition, surprisingly, we find no reflection of it in the contemporary published specialist literature. The most probable explanation is that open criticism of undertakings supported (and financed) by the then Communist government was too risky.

3. Unfortunately, the lively discussions amongst Czech conservators, concerning the aims, strategies, and methods of heritage conservation in the new democratic conditions after the "Velvet Revolution", are not reflected in published texts.

\section{References}

Araoz, G. F. 2012. "Protecting Heritage Places Under the New Heritage Paradigm and Defining Its Tolerance for Change." Pp. 47-52 in Conservation Turn-Return to Conservation, edited by W. Lipp, J. Štulc, B. Szmygin, and S. Giometti. Firenze: Polistampa.

- 2015. On the Need to Develop Criteria to Assess Reconstruciton of Heritage Places. Dubai: ICOMOS.

Denkmalschutz. 1993. "Denkmalschutz: Texte zum Denkmalschutz und zur Denkmalpflege" (Heritage Protection: The Texts on Heritage Protection and Conservation). Schriftenreihe des Deutschen Nationalkomitees für Denkmalschutz (The Row of Written Documents of German National Committee of Heritage Conservation), 52. Bonn: Deutsches Nationalkomitee für Denkmalschutz.

Dostál, O. and A. Vošahlík. 1965. "Obnova západního průčelí bývalého Emauzského kostela v Praze" (The Renewal of Western Front of Emmaus Abbey Church in Prague). Architektura ČSSR (Architecture of the Czechoslovak 
Socialist Republic) 24:581-590.

Fischer, M. 1998. "Rekonstruktionen-Ein geschictlicher Rückblick" (Reconstruction-A Historical Look Back). Pp. 7-10 in Rekonstruktion in der Denkmalplege (Reconstruction in Heritage Conservation). Schriftenreihe des Deutschen Nationalkomitees für Denkmalschutz (The Row of Written Documents of German National Committee of Heritage Conservation), 57. Bonn: Deutsches Nationalkomitee für Denkmalschutz.

ICOMOS. 2013. "ICOMOS Debate on Permissibility and Standards for Reconstructions of Monuments and Sites." ICOMOS ISC on Interpretation and Presentation (ICIP). Paris: ICOMOS.

- 2017. ICOMOS Guidance on Post Trauma Recovery and Reconstruction for World Heritage Cultural Properties. Paris: ICOMOS.

Juránek, J. and K. Braný. 1976. Nové Město nad Metují. Prague: Odeon.

Karásek, J. 2007. "Historie věži”" (The History of Towers). Zprávy památkové péče (The Conservation News) 67:307-309.

Kibic, K. 1984. "Betlémská kaple v Praze a její rekonstrukce" (The Bethlehem Chapel in Prague and Its Reconstruction). Staletá Praha (Centuries-Old Prague) 14:29-40.

—. 2007. "K problematice obnovy hlavního průčelí Malostranské radnice v Praze" (On the Renewal of the Main Front of Town Hall of the Lesser Town of Prague). Zprávy památkové péče (Conservation News) 67:290-300.

Kibic, K. and A. Vošahlík. 2011. Památková ochrana a regenerace historických měst $v$ České republice (The Heritage Protection and Regeneration of Historic Towns in the Czech Republic). Prague: Národní Památkový Ústav.

Kiesow, G. 2012. Denkmalpflege in Deutschland (The Heritage Conservation in Germany). 4th ed. Darmstadt: WBG (Wissenschaftliche Buchgesellschaft).

Mayer, J. 1998. "Dům U Bílého zvonu na Staroměstském náměstí v Praze" (White Bell House on Old Town Square in Prague). Umění (Art) 36:97-126.

Mörsch, G. 2000. "Dehio und die Denkmalpflege" (Dehio and the Heritage Conservation). Pp. 121-135 in Georg Dehio (1850-1932) 100 Jahre Handbuch der Deutschen Kunstdenkmäler (100 Years of the Handbook of German Monuments of Art and Architecture). Munich and Berlin: Deutscher Kunstverlag.

Pächt, O. 1963. "Alois Riegl." The Burlington Magazine 105:188-199.

Pavel, J. 1973. "Max Dvořák ochránce památek” (Max Dvořák, Guardian of Monuments). Monumentorum Tutela 10:225-390.

Petzet, M. 2009. International Principles of Preservation,
Monuments and Sites. Berlin: ICOMOS.

_. 2012. "Conservation/Preservation, Limits of Change." Pp. 261-263 in Conservation Turn-Return to Conservation, edited by W. Lipp, J. Štulc, B. Szmygin, and S. Giometti. Firenze: Polistampa.

Rykl, M. and J. Škabrada. 1996. "Byt ve 2. patře věže domu U zvonu" (A Flat on the Second Floor of the Tower of the House at the Bell). Zprávy památkové péče (The Conservation News) 56:12-16.

Sedláková, R. 1994. Sorela, Česká architektura padesátých let (Sorela, Czech Architecture of the Fifties). Prague: Národní Galerie.

Soós, G. 2011. "From World Heritage to Intangible Cultural Heritage: Global Trends Toward a New Heritage Paradigm." Pp. 73-100 in Protecting and Safeguarding Cultural Heritage, edited by J. Purchla. Krakow: International Cultural Centre.

Štorm, B. 1959. "Péče o památky architektury a cesty její myšlenkové koncepce" (The Paths of Architectural Conservation and Its Theory Concepts). Zprávy památkové péče (Conservation News) 19:57-68.

Strakoš, M. 2014. Po Sorele. Brusel, kov, sklo, struktury a beton (After Sorela. The Brussels, Metal, Glass, Structures and Concrete). Ostrava: Národní Památkový Ústav.

Štulc, J. 1988. "Moderní urbanismus a památková péče" (Modern Urbanism and Heritage Conservation). Památky a príroda (Monuments and Nature) 12:65-77.

- 2007a. "Czech Heritage Preservation Movement and Urban Conservation." Centropa 7.1, January.

—. 2007b. "Naděje, pochybnosti a rizika rekonstrukčních projektů — př́klad domu U Zvonu a Malostranské radnice v Praze" (The Hopes, Hesitations and Risks of Reconstruction Projects). Zprávy památkové péče (Conservation News) 67:310-315.

_ 2011. "The So-called Synthetic Method of Architectural Conservation: The Response of Czech Conservators to the Militant Modern Movement of the Thirties.” Pp. 187-194 in The Image of Heritage. Changing Perception, Permanent Responsabilities, edited by A. Tomaszewski and S. Giometti. Firenze: Polistampa.

- 2012. "Regulation Versus Tolerance in the Approach to Historical Cities: The Czech Experience." Pp. 57-71 in Conservation Turn-Return to Conservation, edited by W. Lipp, J. Štulc, B. Szmygin, and S. Giometti. Firenze: Polistampa.

Švéda, K. 2007. "Emauzy ve 20. století a v současnosti” (The Emmaus Abbey in the Twentieth Century and Today). Pp. 203-215 in Emauzy, Benediktinský klášter v srdci Prahy (Emmaus, the Benedectine Abbey in the Heart of Prague), edited by $K$. Benešovská and $K$. Kubínová. Prague: Academia. 
The Venice Charter (1964). 2004. Pp. 37-38 in International Charters for the Conservation and Restoration of Monuments and Sites, edited by M. Petzet and J. Ziesemer.

Wagner, V. 1946/2005. Umělecké dilo minulosti a jeho ochrana (The Work of Art From the Past and Its Protection). 2nd ed. Prague: Národní Památkový Ústav.

Wirth, Z. 1942-1943. "Metody preventivní ochrany" (The Methods of Preventive Care). Uměni (Art) 14:123-126.

\section{Bio}

Josef Štulc, Ph.D. in history of art and classical archaeology, associated professor at Technology University in Prague, research worker, director of National Heritage Institute (1990-2012), honorary president of Czech National Committee of ICOMOS, Czech Republic; research fields: heritage conservation, medieval architecture. 